\title{
Ethnologies
}

Folksongs and Folk Revival: The Cultural Politics of Kenneth

Peacock's Songs of the Newfoundland Outports. By Anna

Kearney Guigné. (St. John's, Institute of Social and Economic

Research, 2008. Pp. $\mathrm{x}+331$, ISBN 978-1-894725-06-4)

Old-Time Songs and Poetry of Newfoundland: Songs of the

People From the Days of Our Forefathers. By Gerald S. Doyle.

(St. John's, Memorial University of Newfoundland Folklore and

Language Publications, 2008 [1940]. Pp. xxii + 82, ISBN

978-0-88901-404 6).

\section{Mark Finch}

Volume 31, numéro 2, 2010

Figures noires

Black Images

URI : https://id.erudit.org/iderudit/039380ar

DOI : https://doi.org/10.7202/039380ar

Aller au sommaire du numéro

Éditeur(s)

Association Canadienne d'Ethnologie et de Folklore

ISSN

1481-5974 (imprimé)

1708-0401 (numérique)

Découvrir la revue

Citer ce compte rendu

Finch, M. (2010). Compte rendu de [Folksongs and Folk Revival: The Cultural Politics of Kenneth Peacock's Songs of the Newfoundland Outports. By Anna Kearney Guigné. (St. John's, Institute of Social and Economic Research, 2008. Pp. $\mathrm{x}+331$, ISBN 978-1-894725-06-4) / Old-Time Songs and Poetry of Newfoundland: Songs of the People From the Days of Our Forefathers. By Gerald S. Doyle. (St. John's, Memorial University of Newfoundland Folklore and Language Publications, 2008 [1940]. Pp. xxii + 82, ISBN 978-0-88901-404 6).]

Ethnologies, 31(2), 338-341. https://doi.org/10.7202/039380ar d'utilisation que vous pouvez consulter en ligne. 
Folksongs and Folk Revival: The Cultural Politics of Kenneth Peacock's Songs of the Newfoundland Outports. By Anna Kearney Guigné. (St. John's, Institute of Social and Economic Research, 2008. Pp. x + 331, ISBN 978-1-894725-06-4)

Old-Time Songs and Poetry of Newfoundland: Songs of the People From the Days of Our Forefathers. By Gerald S. Doyle. (St. John's, Memorial University of Newfoundland Folklore and Language Publications, 2008 [1940]. Pp. xxii + 82, ISBN 978-0-88901-404 6).

Three interconnected narratives run through Folksongs and Folk Revival. In addition to the central narrative, a biography of "folk music specialist" (235), Kenneth Peacock's (1922-2000) career collecting folksongs in Newfoundland, Guigné provides detailed accounts of the evolution of folklore studies in Canada through the activities of the National Museum, as well as the political and cultural transformations of post-confederation Newfoundland and that province's own folksong revival. As these three histories cross and inform one another, readers are offered a glimpse into the climate of folklore studies in mid-twentieth century Canada.

After having published, recorded, and performed some of his own musical work, by 1949 Peacock was well on his way to establishing himself as a young, up-and-coming classical composer and pianist in Canada. During this time, however, Peacock, like many in Canada, was being pulled by nationalistic motivations away from the European flavour of most of this period's classical music in search of something more representative of his own national culture (77). It was during this period that Peacock had an encounter with archivist Margaret Sargent, who would expose him to the activities and academic culture of the National Museum of Canada. When Sargent resigned from her position at the Museum, leaving behind some unfinished folksong collecting in Newfoundland, she provided Peacock with an entryway into the field that would define much of his career documenting Canadian folk culture.

Chapter 6 outlines Peacock's first two field trips to Newfoundland in 1951 and 1952. Picking up where Sargent left off, Peacock began his collecting on the province's Avalon Peninsula. In her retelling of these trips (complemented with extensive quotes from her interviews with Peacock, excerpts from his notes and field recordings, and photographs 
he took during the visits), Guigné describes what was "a meeting of two cultures" (96). The reader witnesses Peacock's often awkward encounters with residents as he attempts to negotiate his own expectations of a quaint, rural culture, and the appointments he attended with prosperous local interpreters of Newfoundland song in St. John's. Feeling uneasy with his perceived outsider status in the province's urban centre and not discovering the type of singing or singer he was searching for, Peacock would spend the rest of this and future trips exploring outport communities across the island (99-100). Rural Newfoundland reinforced Peacock's romantic vision of a culture untouched by the modern world and, in the face of Confederation, stirred his preservationist motivations. This, along with his own preference for locally-composed songs, shaped much of his research. While the outcome of Peacock's research has resulted in a thorough documentation of Newfoundland's song tradition, his motivations also limited his collection and prevented him from considering the unique repertoires made up of both popular and traditional music (104).

Examining these early trips, Guigné calls attention to Peacock's inexperience as a folksong collector and his discomfort with the academic work of a folklorist. Instead Peacock approached the work as a trained musician, and was concerned primarily with documenting the songs in a manner he felt was accurate, while neglecting to record contextual notes. However, going beyond the easy and often tempting practice of criticizing past work from the privileged position of accumulated theoretical and methodological development, Guigné instead takes the opportunity to build upon and complement Peacock's work. In Chapter 8, for instance, she draws on her own interviews with a singer from St. Paul's, Newfoundland whom Peacock recorded in 1958. Guigné's fieldwork, conducted forty years after Peacock's visit, enhances our understanding of the context in which these songs were learned and performed. Further, she contextualizes Peacock's fieldwork including his shortcomings as a researcher - within the atmosphere of Canadian folklore studies during the mid-twentieth century. This, in turn, leads to an exploration of the folk revival in Canada and the role of the National Museum in producing and disseminating research on the country's folk cultures. Through this account we see the National Museum's early disinterest in Canadian folk culture develop into a romantic nationalist preoccupation with folk culture throughout the country and especially within the maritime provinces and the Confederation's most recent addition, Newfoundland. In this history, 
Guigné also outlines the influence of figures such as Marius Barbeau and Carmen Roy, as the Museum's folklore research became increasingly professionalized, and tensions arose between those who sought to reserve the Museum's archives exclusively for academic work and those who wished to popularize the collections through songbooks and commercial recordings.

Guigné's account of Peacock's research activity and the growth of the National Museum demonstrates how the views of researchers, as well as the contexts in which they work, shape their data and its representation. Likewise, in her discussion of the publication of Peacock's mammoth collection, Songs of the Newfoundland Outports (1965), we witness how folklore research can impact the culture it looks to represent. In the case of Peacock's work, Outports was published just as many Newfoundlanders (especially within St. John's) began to question the vision of post-confederation Newfoundland and a nativist revival of the province's folk culture was emerging. Looking to bring attention to what many urban Newfoundlander's believed was a disappearing local song tradition, throughout the 1970s and 1980s Outports was mined for material by groups such as the St. John's-based Figgy Duff. In addition, singers mentioned in the collection were invited to perform at events in the capital city. Interestingly, as Guigné notes, Outports, which was largely a product of Peacock's own preservationist motives with regards to a culture that he felt was exposed to the threat of modernization, reinforced the views of rural Newfoundland held by many of the urban revivalists.

Folksongs and Folk Revival reads as a compelling biography of Peacock's career and the development of folklore studies in Canada. From a methodological perspective, it demonstrates the usefulness of a historical approach in illuminating issues of representation, context, and reception. More importantly, Guigné exemplifies how folklorists can revisit and strengthen past research, and in the process she augments our understanding of Newfoundland's song tradition and the environment in which it emerged. Of course, Peacock's Outports is just one of several books of Newfoundland song published and embraced by Newfoundlanders during the mid-twentieth century. With the reissue of Gerald S. Doyle's Old-Time Songs and Poetry of Newfoundland (2008/ 1940), Memorial University's Folklore and Language Publications have made available a key text in the production and sharing of a local song tradition among Newfoundlanders. In addition to examining Doyle's interest in collecting and publishing Newfoundland songs, Guigné, who 
also provides an introduction to this volume, illustrates the impact of Old-Time Songs (which at one time was ubiquitous across Newfoundland) on the province's song tradition, and contextualizes it within the Canadian folksong revival which took place in the decade following its initial publication. Aside from Guignés insightful introduction, this release is a facsimile reprint of the 1940 edition and includes Doyle's original introduction, all forty songs, as well as all of the advertisements for the pharmaceuticals offered by Doyle's distributing company. While these publications could benefit from accompanying audio recordings (via an attached CD or related website), both Folksongs and Folk Revival and the reprint of Old-Time Songs are welcome contributions to the study of Newfoundland song.

Mark Finch
Memorial University of Newfoundland

How I Escaped From Gilligan's Is/and and Other Misadventures of a Hollywood Writer-Producer. By William Froug. (Madison, Wisconsin, University of Wisconsin Popular Press, 2005. Pp. 345, ISBN 0-87972-873-6)

William Froug writes about his experiences in the entertainment industry, as he moves from radio to television and finally to teaching, always keeping an eye on the film world but never quite managing to break in. This is not a memoir, though. Froug writes strictly about his career, mentioning his two failed marriages and four children only in passing. He focuses on his rise from a free-lance writer for radio to a full professor in UCLA's department of Film, Theatre Studies, and Television, setting his own career ascent against the decline of radio and the rise and fall of the so-called "golden age of television". Loaded with backstage tales, gossip and rumours, Froug is not only willing to spill the beans on famous co-workers but also on himself, even when it paints him in an unflattering light. He speaks candidly both about having to fire people as well as his own, numerous experiences of being fired.

Froug begins his narrative reminiscing on his time as a naval officer at the end of World War II. His bored shipmates seek his permission to shoot sharks in the water, and Froug likens this to the sharks in 